\title{
Solid waste management in Minna, North Central Nigeria: present practices and future challenges
}

\author{
Peter Aderemi Adeoye ${ }^{1^{*}}$, Mohammed Abubakar Sadeeq², John Jiya Musa², Segun \\ Emmanuel Adebayo ${ }^{2}$ \\ ${ }^{1}$ Department of Biological and Agricultural Engineering, Universiti Putra, 43400 UPM
} Serdang, Malaysia

${ }^{2}$ Department of Agricultural and Bioresources Engineering, Federal University of Technology, P.M.B. 65, Minna, Nigeria

Received: 12 October 2011

Revised: 19 November 2011

Accepted: 20 November 2011

Key words: Solid waste, treatment, management and environment.

\begin{abstract}
This review presents a brief trend in Minna Municipal solid Waste (MSW) management. Municipal solid waste is a major environmental problem in Minna as in many developing towns. Although strict regulations on the management of solid waste are in place, primitive disposal methods such as open dumping and discharge into surface water are still being used in various parts of the town. The review also presents the MSW management structure together with the present situation of generation composition, collection, disposal and treatment. It also provides a brief discussion on the future challenges. Waste generation increases by more than 200\% within two decades and increase in budgetary allocation is not proportional to the waste generation increase. The waste management agency did not have enough resources to tackle the ever increasing Municipal Solid Waste. The collection process is deficient in terms of manpower and vehicle availability. Bin capacity provided is inadequate and their locations were found to be inappropriate, thus contributing to the inefficiency of the system. At this time, no treatment is provided to the waste after collection. Under- estimation of waste generation rates and inadequate management and technical skills were also responsible for inappropriate waste management system in the town.
\end{abstract}

${ }^{*}$ Corresponding Author: Peter Aderemi Adeoye $\bowtie$ pheterhardey@yahoo.com 


\section{Introduction}

Municipal solid waste management (MSWM) will continue to be a major challenge facing countries all over the world. Especially for developing countries, where the amount of municipal solid waste (MSW) has increased greatly due to rapid increase in urban population (Adebayo et al, 2006). Meanwhile, with limited resources, only basic technologies for treatment and disposal, and deficient enforcement of relevant regulations, serious problems remain for MSWM in developing countries, especially in regard to safe disposal. The progress of modern civilization and the associated increase in population worldwide has contributed significantly to the increase in the quantity and variety of waste generated (Anikwe and Nwobodo, 2002). The increase in consumption of resources has resulted in large amounts of solid waste from domestic activities and can lead to significant threats to human health. Improper management of solid waste has serious environmental and health consequences, their environmental effects include pollution of surface and subsurface waters, unpleasant odours, pest infestations, and gas explosions (Ayo and Mohammed, 2010). Due to inadequate waste disposal, surface and groundwater are contaminated by leachate and the air is polluted by burning of waste or uncontrolled release of methane from anaerobic waste decomposition (Sha'Ato et al, 2007). The hazards associated with improper solid waste disposal and the associated environmental health impact should therefore be of utmost concern to waste management experts. If waste pollution continues unchecked, it may lead to unprecedented health consequences (Chen and Fujita, 2010).

Waste management is a global issue which needs maximum attention. In developing countries, waste management agencies lack the resources and trained staff to provide their rapidly growing populations with the necessary facilities and services for solid waste management to support good quality of life (Pokhrel and Viraraghavan, 2005). Within the framework of sustainable development, developing countries today face the challenge of balancing economic growth with environmental progress. The indiscriminate dumping of MSW is increasing and is compounded by a cycle of poverty, population explosion, decreasing standards of living, poor governance, and the low level of environmental awareness .Hence, these wastes are illegally disposed of onto any available space, known as Open-dumps (Izugbara and Umoh,2004). The collected waste is generally dumped on land in a more or less uncontrolled manner. Such uncontrolled waste disposal not only creates serious environmental problems and affects human and animal health, but also causes serious financial and socio-economic losses (Kalu et al, 2009). The potentials of residents to generate waste have increased in recent times due largely to accelerated urbanization, and population growth, which have elicited strong international concerns about the possible environmental, health and safety effects of living in the vicinity of these open-dumps. The only way to prevent this is to assess the level of waste generation, its management techniques and available disposal facilities. The objective of this paper is therefore to analyze some of the strengths and deficiencies in the current MSW management system in Minna, a fast growing city in North central Nigeria and propose feasible solutions.

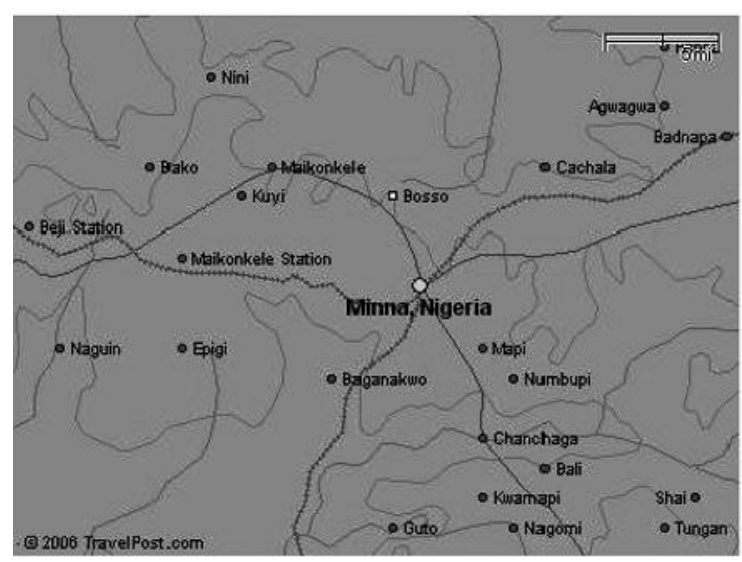

Fig. 1. Map of Minna, Niger state, Nigeria.

\section{Minna}

Minna, the capital city of Niger State, Nigeria has a total population of approximately 506,113. The average population density in Minna is about 3448 persons per $\mathrm{km}^{2}$ (UNDP/NISEPA, 2009). The 
population growth in the city is higher than the average of the whole country because of its proximity to Abuja, the new administrative capital of the country. This shows that there may be a rapid population inflow into the city, perhaps because of job opportunities in Federal Capital Territory. However, more people means more waste, and more waste means more resources needed for waste management, the rapid population inflow should be considered in designing a waste management plan (Manaf et al, 2009). Being a small and densely populated town with a hot and dry climate, average temperature of $26.7-35.3^{\circ} \mathrm{C}$, daily average humidity at $44.4 \%$, and annual average rainfall of $1334 \mathrm{~mm}$, Minna is potentially vulnerable to the outbreak of any infectious diseases. At the same time, rapid population growth continues to contribute to the burden of solid waste disposal. Solid waste management in the town has traditionally been undertaken by the Niger State Environmental Protection Agency (NISEPA). Minna is a multiethnic, multi-cultural, and multi-lingual society. Its economy was once exclusively based on agricultural commodities, and now it is still one of the world's largest producers of maize, sorghum, beans, rice, yam and millet. Minna was made first headquarter of Chanchaga local government since the creation of Niger State in 1976, although it still maintain its status of headquarter of Minna municipal council with all administrative and functional requirement of a full pledge local Government. However when the defunct Chanchaga local government was moved to Kuta and named Shiroro local government, it then gained her autonomy of local government in July 1989. The creation of additional local government in 1991 saw the split of chanchaga local government into the three to have Paikoro and Bosso L.G.A in addition, Figure 1 . The town lies on longitude $9^{\circ} 37^{1} \mathrm{~N}$ and longitude $6^{0} 33^{1} \mathrm{E}$, on geographical base of undifferentiated basement complex rock of mainly quiets and magnatile situated at the base of prominent hills in an undulating plain. The whole of Minna surrounding is very rock. The typical climate of the middle beet zone of Nigeria is a good reflection of Minna climate, with rain season starts around April and last till October. The month of September normally records highest rainfall. The mean monthly temperature is highest in March and lowest in August (UNDP/NISEPA, 2009).

\section{Waste generation and characteristics in minna}

Solid waste in Minna is broadly classified into three main categories: Domestic refuse (solid waste generated by households, markets, food centers and commercial premises such as hotels, restaurants, etc.). Industrial refuse (not including toxic and hazardous waste) and Institutional refuse (solid waste from various government installations like hospitals, schools and recreational facilities. Fig. 2 shows the actual amount of solid waste disposed of in tonnes in the last two decades1987-2009 in Minna city (UNDP/NISEPA, 2009).

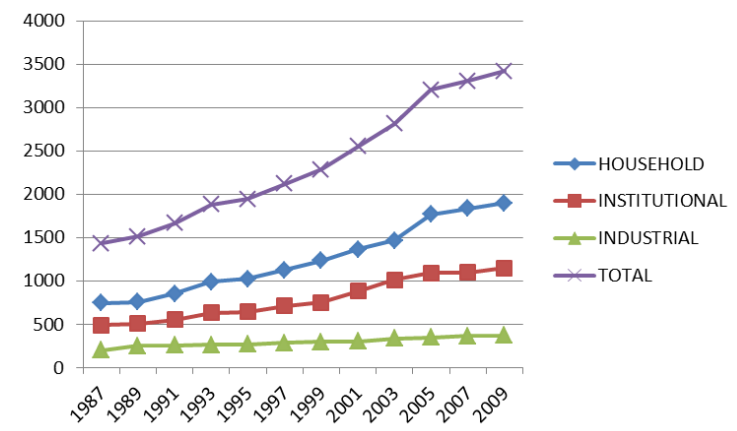

Fig. 2. Waste Disposed of in Minna for the past two decades.

From Fig. 2, the total solid waste in 2009 was almost three times waste generated in 1987. Domestic solid waste has increased greatly over the years, from 640tonnes to 1893 tonnes in the years under review. This may be as a result of an increase in both population and per capita waste generation rate due to improved standard of living. The population was 152,603 in 1987 and 506,113 in 1997 therefore the average rate of domestic waste being disposed of was $0.238 \mathrm{~kg}$ /day in 1987 and $0.267 \mathrm{~kg} /$ day in 2007 per capita (UNDP/NISEPA, 2009). There is no remarkable increase in industrial waste within the two decades as the town did not experience much 
industrial growth, from 20otonnes in 1987 to 377tonnes in 2009. The percentage increase in institutional solid waste has increased. This was due largely to heavy presence of federal Agencies and location of Institutions in the town within the two decades. It increases from 487tonnes in 1987 to 1150tonnes in 2009 (Ogwueleka, 2009).

Table 1. Solid wastes composition in Minna between 1987 and 2007.

\begin{tabular}{lccccc}
\hline Composition of wastes (\%) & year & & & & \\
\cline { 2 - 6 } & 1987 & 1992 & 1997 & 2002 & 2007 \\
Food/Organic wastes & 36.45 & 36.61 & 40.58 & 42.10 & 42.58 \\
Paper/Textiles/Leather & 24.65 & 25.61 & 22.83 & 22.05 & 21.09 \\
Plastics & 6.02 & 6.91 & 5.64 & 5.93 & 5.91 \\
Construction debris & 5.60 & 5.60 & 8.65 & 8.69 & 8.75 \\
Wood & 3.22 & 2.64 & 2.64 & 2.69 & 3.01 \\
Horticultural wastes & 4.53 & 1.96 & 2.03 & 2.01 & 2.05 \\
Metals (Ferrous and non- ferrous & 2.02 & 2.61 & 3.61 & 3.52 & 3.61 \\
Sludge & 0.09 & 0.07 & 1.20 & 1.45 & 1.49 \\
Glass & 1.02 & 1.04 & 1.15 & 1.14 & 1.11 \\
Scrap tyres & 0.44 & 0.61 & 0.94 & 0.94 & 0.87 \\
Pampers/sanitary pads & 5.26 & 6.58 & 7.59 & 7.59 & 7.84 \\
Others & 10.70 & 9.76 & 3.14 & 1.89 & 1.69 \\
\hline
\end{tabular}

Table 2. Wastes composition for different districts in Minna.

\begin{tabular}{lcccccccc}
\hline Waste Type (\%) & \multicolumn{7}{c}{ Districts Name and characteristics } \\
\cline { 2 - 9 } & Chanchaga & Bosso & Tunga & Maikunkele & Kpakungu & Shango & Maitumbi Tudun fulani \\
Food Remnants & 51.14 & 56.40 & 53.41 & 49.61 & 53.22 & 49.61 & 49.36 & 49.26 \\
Pampers/sanitary & 6.41 & 5.69 & 5.66 & 5.39 & 6.21 & 4.36 & 4.84 & 4.16 \\
pads & & & & & & & & \\
Glass & 5.91 & 4.33 & 6.41 & 6.29 & 5.62 & 5.16 & 5.44 & 7.01 \\
Metals & 7.92 & 6.41 & 6.54 & 6.23 & 6.43 & 6.44 & 6.41 & 6.33 \\
Paper & 2.46 & 5.61 & 3.44 & 4.49 & 2.46 & 1.46 & 1.23 & 3.99 \\
Plastics & 16.30 & 11.6 & 11.4 & 12.09 & 13.33 & 12.90 & 13.01 & 12.11 \\
Wood & 6.10 & 7.20 & 6.4 & 6.90 & 5.40 & 10.30 & 9.56 & 5.40 \\
Others & 0.76 & 2.76 & 6.74 & 9.00 & 7.33 & 9.77 & 10.15 & 11.74 \\
Total & 100 & 100 & 100 & 100 & 100 & 100 & 100 & 100 \\
\hline
\end{tabular}

Table 2 presents the percentage distribution of solid waste in Minna from 1987 to 2009. Food waste remains the highest portion, closely followed by paper, and sanitary pads. The comparison of national waste statistics may not be too simple a task, due to the difference in compositional classifications and data gathering system, solid waste composition in Minna is quite similar to that in Kolkota, India (Hazra and Goel, 2009), but vary slightly from those in Phnom Penh city in Cambodia (Kum, et al, 2005). Food waste accounts for about $37 \%$ of the total waste streams and paper makes up 25\%. Food and paper waste in Kolkota was about 39.6 and $25.5 \%$ of its total solid waste respectively (Hazra and Goel, 2009). There are about 68.0 and $48.7 \%$ of food and paper waste respectively in Phnom Penh almost doubled the percentage in Minna. The differences in solid waste composition can then have a serious impact on 
the techniques of solid waste management in different countries. Combustibility of a waste depends largely on its calorific values and varies substantially depending on the source and the period of the year. Therefore, incineration cannot be recommended generally for waste management unless the calorific properties of the waste are known and it has to be site specific (Ogwueleka, 2009).

Table 2 provides composition of the solid wastes produced in eight major locations in Minna. The main components are food residues, plastics, paper, glass bottles and metals. The table also shows that the plastic content is unusually high probably because it was wet, which increased the weight. Plastics mainly come from water and fruit juice bags and containers. Much of this material is in small pieces, mixed types; wet, dirty and hence recycling may be difficult. The results of the analysis also show that the generated waste in the city is largely organic matter that can be composted. The waste is also heterogeneous in composition comprising of both degradable and non-degradable materials, therefore of collection vary substantially from one area to another (UNDP/NISEPA, 2009). Moreover, the transportation of waste to the dump-site has not been properly managed. Wastes that are light in weight are clearly seen flying from the trucks during transport. This also contributes to the litter on streets. It seems that the collection service in the city is deteriorating, in many areas, the frequency of collection has dropped from once a day to once every three days and collection times are quite variable. As a result of this more and more households carry their waste to the nearby dumpsites popularly known as bolah inside waste-bags and thereby littering the street during transport. The waste bags can also be torn by scavenging animals and humans that search for something to eat searching for saleable materials. These activities usually scatter the waste that is ready for collection, and this makes the job of the collection crew even more difficult, as they have to shovel the scattered waste from the ground into the collection vehicle. This system leads to unacceptably low sorting at site would have been an appropriate method for collection (Osman, 2009). The bulk of the non-degradable waste is potentially recyclable materials, while the degradable materials could be composted.

\section{Solid wastes collection system in Minna}

Collection and transportation of waste is both labour and capital intensive. Waste transportation, including labour and machinery, accounts for between $70 \%$ and $80 \%$ of the total cost of solid waste management in Nigeria. (Imam et al, 2008). A shortage of waste collection vehicles in Minna is due to lack of funding and inadequate maintenance. Efficient collection depends on proper selection of vehicles; this needs to take account of road conditions, traffic density, availability of spare parts and servicing requirements. Waste collection service is available only in places where there are good roads. It was estimated that more than $35-40 \%$ of the population in the city is without regular or adequate collection service and the coverage, efficiency and frequency collection efficiency and too much waste is left on the streets of Minna.

The existing collection system should be replaced with a more efficient, but not more expensive system without delay. Waste scattered from the collection trucks during transportation is due to the lack of adequate cover during the trip. This can be alleviated by covering the waste during transport especially if the vehicle is travelling at more than $35 \mathrm{~km} / \mathrm{h}$. The use of compactor trucks for the transportation of waste as a means of enclosing waste during transport may also be considered, a compaction vehicle is designed for the waste volume reduction because on the average, such a vehicle will reduce the density of the waste to about $450-520 \mathrm{~kg} / \mathrm{m}^{3}$ from the initial density of $200-250 \mathrm{~kg} / \mathrm{m}^{3}$. However, the compactor trucks are very expensive and require high operating cost and also complex additional maintenance, but its usage will solve the problem of scattering of waste 
during transportation to the dump-sites (Sarwoko, et al, 2007).

\section{Waste disposal in Minna}

Solid wastes from the different collection system in the various districts in Minna are transported to various dump-sites at the outskirts of the city. Piles of solid wastes are also found along roads, underneath bridges, in culverts and drainage channels and in other open spaces. This practice should not continue because it is not environmentally acceptable, and it makes environment unhealthy and unhygienic. The involvement of citizens in environmental sanitation is important, in Minna and of course in most Nigerian cities, every Saturday has been declared the environmental sanitation day. Most people now commit this day to clean their local environment. Civil servants now devote at least two hours a day in the week to cleaning their office premises. Through this measure, people are being made aware of the need to clean environment. The environmental sanitation day however causes problems, because people have no means of disposing the waste collected. Vehicle owners parked the wastes in their car and dump them along the major roads leading out of Minna. Though people participate in this cleaning up exercise, they should be educated on how to dispose of the waste properly.

It is still common in Minna to see people throw litter from cars or motor vehicles into streets while traveling and to see people in the parks leave litter on the streets even though rubbish bins are situated within walking distance. This is really a lack of responsibility and has a negative effect on the environment. People at times deliberately dump their waste into open channels thinking that it will be carried away by rainwater, not understanding the clogging and pollution problem this may cause. In the medium or higher income areas, the situation is a bit better people leave their waste inside plastic bags along the streets but these bags of waste become scattered by scavengers. This also shows that the general public has not been fully sensitized to participate actively in waste management issues. There is therefore a need for a greater public participation for better SWM in Minna city. The environmental issues can be included in the school curriculum so that the concept of waste management will grow with the students as they progress in life, this will build human resources for future generations.

\section{Future challenges}

The changes in lifestyle, particularly in the urban areas, have led to more acute waste problems. The situation is further worsened in the sub-urban areas and in slum areas with additional problems of closely-packed housing and traffic, where air and water pollution are experienced. Indiscriminate dumping in open places, access roads and watercourses are the problems that are widespread, which are human contribution to a public health problem. Thus, the challenges of sustainable development are population explosion lack of infrastructure and environmental pollution as causes and impacts. Wastes should be managed in such a way that our present and even coming generations will not be affected; this is because this environment is not inherited from our ancestors but just borrowed from our offspring (Turan et al, 2009). Scavenging activities should be discouraged. Soil cover should also be utilized, and the landfill be constructed. Recycling is still at zero level in Minna, nonetheless, with increasing environmental awareness; the government should start to promote waste recycling by drafting policies and offering support to private waste management companies. Waste minimization will remain to be one of the major future challenges; it therefore needs to be implemented more strictly. Currently, there is no limitation on the amount of solid waste that may be generated; minimization of residential solid waste will continue to be difficult until the regulation of Pay-As-You-Throw is fully implemented. Environmental protection campaigns should also be frequently launched, with the media always playing an important role. Biological 
treatment of organic solid wastes, such as composting and anaerobic digesting, has played an important role in many other countries. Food waste, for example, accounted for about $37 \%$ of the total solid waste in Minna but only $2.3 \%$ of it was recycle (Solomon, 2009). Non-toxic contaminated food waste should therefore be separated for biological treatment. This will reduce the energy consumption and cost needed for the incineration of food waste which is high in moisture content. Composted food waste can then be used for agricultural activities.

\section{Conclusions and recommendations}

It is widely accepted that solid waste management issues should be addressed from a system perspective by taking into account the technological, financial, institutional, legal, and socio-cultural factors to determine appropriate policies for the local surroundings (Salim, 2010). Rapid urbanization and population explosions has caused tremendous increase in solid waste generation in Minna. Appropriate storage systems at the sources of waste generation should be introduced into the waste management system in the city. Regulations regarding littering and improper disposal of solid waste should be formulated, and stiff penalties should be imposed on defaulters. Public awareness about the environment should be increased through environmental education so that the public participation in SWM will improve. A source reduction program should be encouraged and promoted because it is a way to address waste prevention. It is clear from government and general public actions that there is a need to have a clean environment. Many things still need to be done to ensure proper waste management. The campaign on environmental sanitation should be strengthened, it should be inculcated into daily life of every citizen, the number of people employed in environmental related jobs are so few that they cannot cope with the volume of waste generated, more people should be employed, cleaning up exercise should not be limited to when an important personality is visiting the city, it should be continuous and permanent. There should be only one major disposal area and should be operated as sanitary landfill site, this, though expensive, will be needed to eradicate littering the roadsides with rubbish.

\section{Acknowledgements}

We hereby acknowledge the assistance of Niger State Environmental Protection Agency (NISEPA) and Niger State Ministry of Environment in preparing this paper.

\section{References}

Adebayo WO, Bamisaye JA, Akintan OB, Ogunleye OS. 2006. Waste generation, disposal and management techniques in an urbanizing environment: A case Study of Ado-Ekiti, Nigeria. Research Journal of Applied Sciences 1(4), 63-66.

Anikwe MAN, Nwobodo KCA. 2002. Long term effect of municipal waste disposal on soil properties and productivity of sites used for urban agriculture in Abakaliki, Nigeria. Bioresource Technology 83(3), 241-250.

Ayo B, Ibrahim B, Mohammed RM. 2010. The practice and challenges of solid waste management in Damaturu, Yobe state, Nigeria. Journal of Environmental Protection 1, 384-388.

Chen X, Geng Y, Fujita T. 2010. An overview of municipal solid waste management in China. Waste Management 3o(4), 716-724.

Hazra T, Goel S. 2009. Solid waste management in Kolkata, India: Practices and challenges. Waste Management 29(1), 470-478.

Imam A, Mohammed B, Wilson DC. Cheeseman, CR. 20o8. Solid waste management in Abuja, Nigeria. Waste Management 28(2), 468472.

Izugbara CO, Umoh JO. 2004. Indigenous waste management practices among the Ngwa of 
Southeastern Nigeria: some lessons and policy implications. The Environmentalist 24(2), 87-92.

Kalu C, Modugu WW, Ubochi I. 2009. Evaluation of solid waste management policy in Benin metropolis, Edo State, Nigeria. African Scientist, 10(1), 117-125.

Kum V, Sharp A, Harnpornchai N. 2005. Improving the solid waste management in Phnom Penh city: a strategic approach. Waste Management 25(1), 101-109.

Manaf LA, Samah MAA, Zukki NIM. 2009. Municipal solid waste management in Malaysia: Practices and challenges. Waste Management 29(11), 2902-2906.

Ogwueleka TC 2oo9. Municipal solid waste characteristics and management in Nigeria. Iranian Journal of Environmental Health Science and Engineering 6(3), 173-180.

Osman NA. 2009. Comparison of old and new municipal solid waste management systems in Denizli, Turkey. Waste Management 29(1), 456-464.

Pokhrel D, Viraraghavan T. 2005. Municipal solid waste management in Nepal: practices and challenges. Waste Management 25, 555-562.
Salim CJ. 2010. Municipal solid waste management in Dar Es Salaam city, Tanzania. Waste Management 3o, 1430-1432.

Sarwoko M, Agus PP, Alim FR, Ananto YS, Muhammad S. 2007. Priority improvement of solid waste management practice in java. Journal of Applied Science in Environmental Sanitation 2(1), 29-34.

Sha'Ato R, Aboho SY, Oketunde FO, Eneji IS, Unazi G, Agwa S. 2007. Survey of solid waste generation and composition in a rapidly growing urban area in Nigeria. Waste Management 27, 352358 .

Solomon US. 2009. The state of solid waste management in Nigeria. Waste Management, 29, 2787-2790.

Turan NG, Atoru S, Akdemir A. Ergun ON. 2009. Municipal solid waste management strategies in Turkey. Waste Management 29(1), 465-469.

UNDP/NISEPA. 2009. Niger state framework for integrated sustainable waste management. Niger State Strategic Waste Management Framework. 